


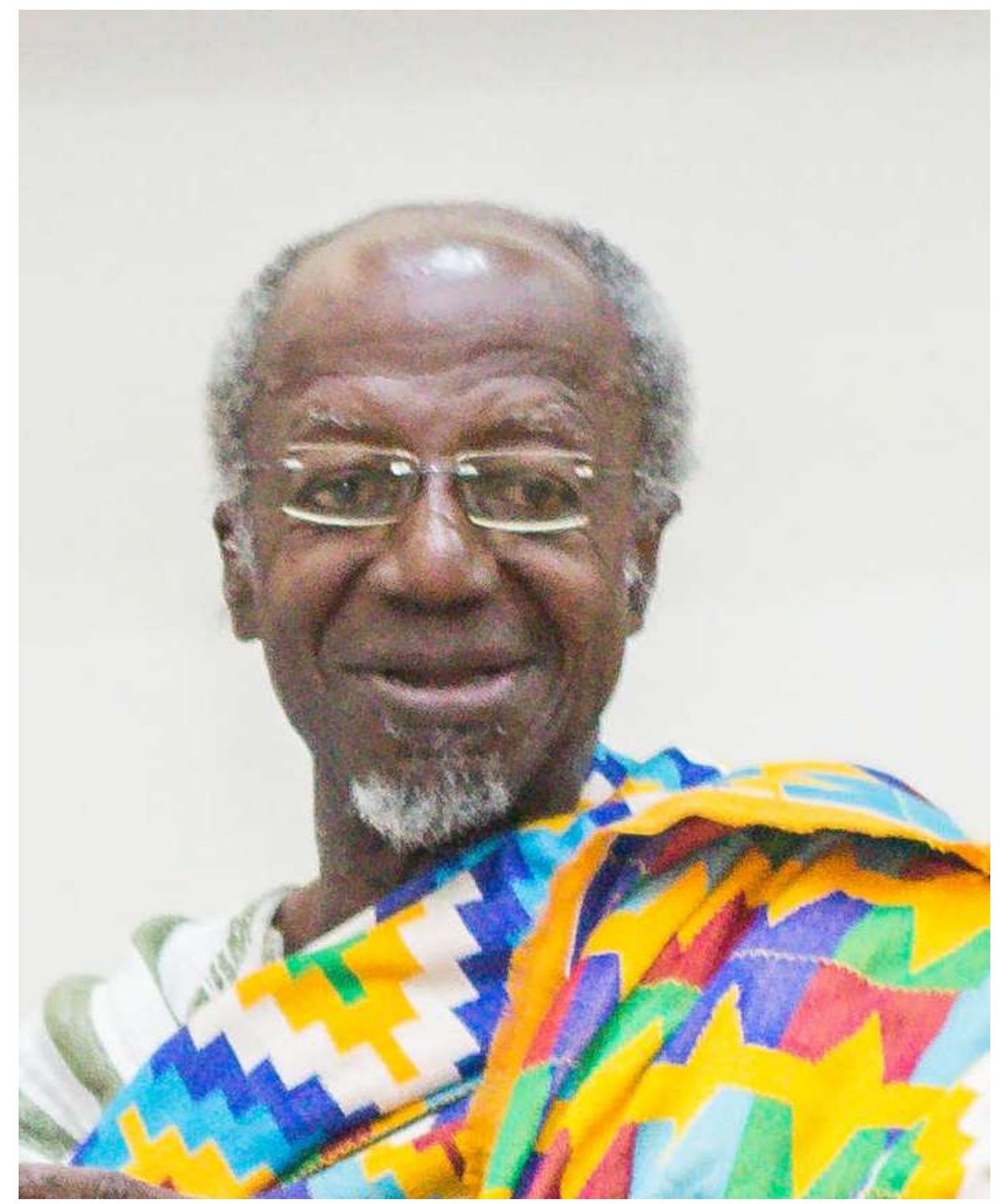

PROFESSOR ATTA GYAMFI BRITWUM 


\section{THE BILINGUAL LITERARY JOURNAL OF THE FACULTY OF ARTS UNIVERSITY OF CAPE COAST}

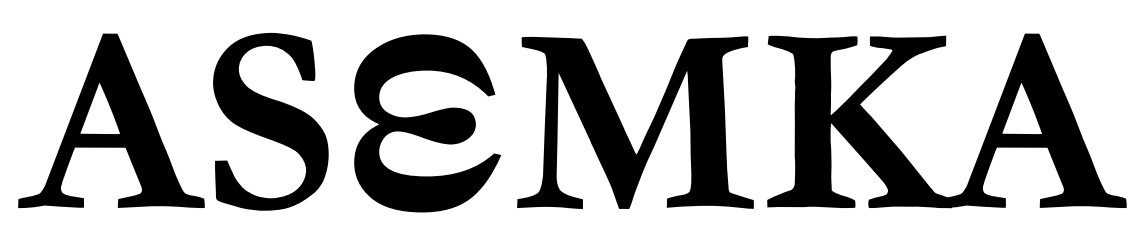

NUMBER 10

SEPTEMBER 2020

\section{EDITORIAL COMMITTEE}

Editor-in-Chief: Prof. Samuel Awuah-Nyamekye (Ph.D.)

Editor: $\quad$ Prof. Mawuloe Koffi Kodah (Ph.D.)

Associate Editors: Dr. Samuel Kwesi Nkansah

Dr. Mrs. Theresa Addai Munumkum

Dr. Isaac Mwinlaaru

Business Editor: Rev. Sr. Dr. Matilda Alice Nsiah

\section{EDITORIAL STAFF}

Mr. Stephen Owusu-Amoh

Mr. Isaac Kweku Grantson

\section{EDITORIAL ADVISORS}

Prof. Kwadwo Opoku-Agyemang, University of Cape Coast.

Prof. Joseph B. A. Afful, University of Cape Coast.

Prof. Raymond N. Osei, University of Cape Coast.

Prof. Richard V. Cudjoe, University of Cape Coast.

Prof. Victor K Yankah, University of Cape Coast.

Dr. Mousa Traore, University of Cape Coast. 


\section{ACKNOWLEDGEMENTS}

We acknowledge the contribution of the underlisted members of the Department of French who did preliminary editorial work on the papers:

Dr. Anthony Y.M. De-Souza (Chairman)

Prof. Raymond N. Osei

Prof. Mawuloe K. Kodah

Dr. Sylvester P. Krakue

Mr. Ofosu Addo-Danquah

Mr. Micheal Donkoh (Secretary)

\section{SUBSCRIPTION}

Assmka is published twice in the Academic year by the Faculty of Arts, University of Cape Coast. The annual out-of-Ghana subscription rate, including air-postage, is US\$29 for individuals, and US\$ 59 for institutions and libraries. Single issue rate for individuals is US\$18. Claims for copies not received must be made within three (3) months following an issue's publication. Correspondence should be addressed to:

The Editor, Assmka

Department of French

Faculty of Arts

College of Humanities and Legal Studies

University of Cape Coast

Cape Coast

Ghana, West Africa

Email: asemkajournal@ucc.edu.gh

\section{ADVERTISING}

Advertising rate, size specifications and related information are available upon request. Please, contact the General Editor for more information.

\section{SUBMISSIONS}

Assmka is an internationally-refereed journal of the Humanities. It publishes scholarly and imaginative articles in Literature, Language, and Culture generally, including, Orature, Film, Theatre, Music and Art. Essays, Interviews, Book Reviews, Poetry, Short Prose Fiction and Drama are welcome. Submitted manuscripts, in English and French, must be prepared in accordance with the most recent of APA or MLA style manual, where applicable. The author's identity and address may appear only on the cover- 
page and nowhere else within the submitted manuscript. All manuscripts should be submitted electronically through:

asemkajournal@ucc.edu.gh

Manuscript will be duly acknowledged within two (2) months of receiving them. Individuals whose works are accepted for publication may provide Assmka with a brief bio-data. The Editors cannot be held liable for lost or damaged manuscripts. Material published by Assmka does not necessarily represent the views of the Journal's Editors, Staff, Financial Supporters or the University of Cape Coast and its affiliates. These parties disavow any legal responsibility related to all submitted material.

\section{BACK ISSUES}

Back issues of Ascmka that are in stock may be ordered from the Editor at US\$20 per copy.

\section{GRANT SUPPORT}

Assmka is funded through grants from the Office of the Dean, Faculty of Arts; the Publications' Board; and the Office of the Vice-Chancellor, University of Cape Coast, Cape Coast, Ghana.

No part of this Journal may be reproduced, stored in a retrieval system, or transmitted in any manner whatsoever without express permission from the Editors, except in the case of brief quotations embodied in critical Articles and Reviews.

Copyright (C2020 by The Editors and The Faculty of Arts, University of Cape Coast. The cover and page design elements were inspired by the Adinkra symbols of Ghana. 


\section{DEDICATION \\ PROFESSOR ATTA GYAMFI BRITWUM}

Professor Britwum is a man of many parts. He is as much at home with Marxist Economic Theory and Feminist Sociological Thoughts, as he is with French and Francophone Literatures. He is a great teacher and Administrator of international acclaim. The Editors dedicate this special issue of Assmka to his honour. 


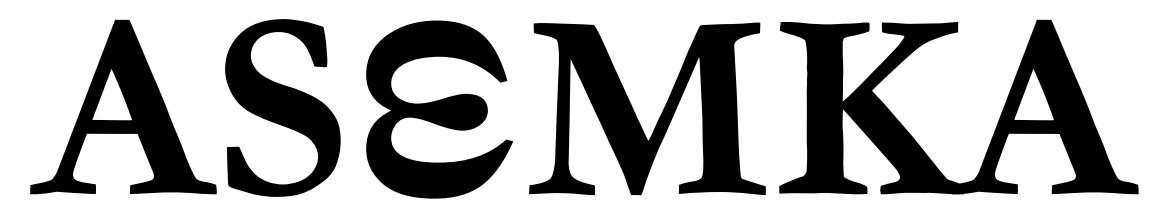

NUMBER 10

SEPTEMBER 2020 


\section{CONTENTS}

$\begin{array}{llll}\text { Editorial Committee } & \sim & \sim & \sim i i \\ \text { Editorial Staff } & \sim & \sim & \sim i i \\ \text { Editorial Advisors } & \sim & \sim & \sim i i \\ \text { Acknowledgements } & \sim & \sim & \sim i i i \\ \text { Subscription } & \sim & \sim & \sim i i i \\ \text { Advertising } & \sim & \sim & \sim i i i \\ \text { Submissions } & \sim & \sim & \sim i i i \\ \text { Back Issues } & \sim & \sim & \sim i v \\ \text { Grant Support } & \sim & \sim & \sim i v \\ \text { Dedication } \sim & \sim & \sim & \sim \\ \text { Foreword } \sim & \sim & \sim & \sim x \\ \text { Assmka: Editorial } & \sim & \sim & x i-x v i i\end{array}$

Articles

First Section - French

Britwum, A. G.

Insuffisances Théoriques Des Damnés De La Terre De

Frantz Fanon

$\sim$

$\sim 2-15$

Kodah, M. K.

Disculpation de Dieu dans le malheur des hommes:

Une lecture critique de Gouverneurs de la rosée de

Jacques Roumain $\sim \sim \sim 16-31$

Addo-Danquah, $O$.

Le récit de pensées: Une analyse comparative de Vol de nuit d'Antoine de Saint-Exupéry et La Condition humaine d'André Malraux

Kodah, M. K. \& Togoh, A. A. X.

Réactions des femmes face au conflit de genre dans C'est le soleil qui m'a brûlée et Tu t'appelleras Tanga de Calixthe Beyala

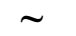

$\sim$

$\sim \quad 45-59$ 
Kudi, M. D.

La Littérature francophone face aux médias de télécommunication : Une nouvelle dynamique de la création romanesque, le cas de L'Énigme de retour et Tout bouge autour de moi de Dany Laferrière $\sim \quad$ 60-72

Gli, $M$.

Les faces du bonheur dans Vol de nuit d'Antoine de Saint-Exupéry $\sim \sim 73-85$

Krakue, S. P.

Christ haïtien : Gouverneurs de la rosée et La Bible $\sim 86-93$

Afari, E. S. K. \& Yegblemenawo, C. A. A.

Apports de la télésérie à l'amélioration de la compétence d'expression orale du FLE à l'école normale $\sim 94-116$

Bationo, J.-Cl.

Didactique de la littérature et littérature didactique:

l'exemple de la littérature africaine francophone en classe de langues étrangères au Burkina Faso

Second Section - English

Krakue, S. P.

Quod erat demonstrandum: A comparative study of narrative technique in Ama Ata Aidoo's Changes and Albert Camus'

Les justes (The Just Ones) 〜 $\sim$ $133-141$

Adjandeh, E. A.

Analysis of Wole Soyinka's Trials of Brother Jero in Relation to Ghanaian Religious Discourse

Sam, C. A.

Decolonizing the Postcolony: Of Men, Spatial Politics and the New Nation in WA Thiongo's Wizard of the Crow.

Kambou, M. K. \& Traore, S. A.

Manipulation and the popular uprising in Burkina Faso in 2014. $\sim \quad \sim 172-189$ 
De-Soura, A. Y.M.

Test-taking Strategies of University of Cape Coast Students of

French as a Foreign Language: a Case Study $\sim 191-216$

Kambou, M. K. \& Soma, L.

Local Culture and EFL Vocabulary Learning $\sim \quad 217-238$

Kabore, A. \& Nazortin, C.

Critical Analysis of the Place and Importance of Literature in the Teaching / Learning of English and in School Leaving Certificate Examination in Burkina Faso from 1985 to 2018

Malgoubri, I., Sawadogo, M. \& Kambou, M. K.

Digital Audio-visuals Aids and Listening in English as a

Foreign Language Classrooms

Osei, R. N. \& Inusah, $H$.

A Critique of the Images of Heaven in the Scriptures of the

Abrahamic Religions: An Existentialist Perspective $\sim$ 270- 282

Negedu, A. K.

Lexical Gaps and Ideological Shift in the Translation of

Chinua Achebe's Things Fall Apart as "Le Monde

S'effondre" in French $\sim \sim 283-297$

Talburt, $T$.

Political Transformation and Development in Africa:

Lessons from Achebe's Things Fall Apart

$\sim 298-313$ 


\section{FORWORD}

All the papers in this Volume were presented at a three-day Conference in honour of Professor Atta Gyamfi Britwum who turns eighty years in March 2021. Most of those years he spent at University of Cape Coast, having cut his teeth as a young lecturer in French language and Literature-in-French in 1974. After many years of an illustrious career in teaching, publication and extension, he bowed out at age seventy, but he didn't get the well-deserved rest he was entitled to; he continues to support his Department and the University as a whole. Today, Professor Britwum's name is associated with high standards of professionalism which earned him the nickname 'L'oracle'. Indeed, it is impossible to find another name universally acknowledged as embodying the excellence in French education offered at the Department of French, University of Cape Coast.

The decision to honour Professor Britwum couldn't have been taken at a more appropriate time. It was planned to coincide with the fiftieth anniversary of the publication of the Beautyful ones are not yet Born, Ayi Kwei Armah's first novel. Britwum never grew tired of reading, teaching and examining it. Such was his respect for Armah's craft. So, the three-day Conference was as much a celebration of Armah's contribution to the shaping of the African novel as it was a tribute to Professor Britwum's work as a teacher of literature of immense influence.

One only has to look at the titles of the papers published in this Volume to get an idea of how deep his influence runs at UCC and beyond. Most of the contributors once upon a time sat at the master's feet, but are now scholars in their own right keeping the flame of French scholarship burning bright (George Cooper: "Polished in a high degree, as each froggie ought to be/Now they sit on other logs, teaching other little frogs.") A good number of the papers are on Literature, nonetheless not limited to Armah's works. No Surprise there. Nevertheless, there are Language papers there too. No surprise here either, for the man to whose honour the Volume is dedicated is equally at home in both Language and Literature

\section{Lawrence $K$. Owusu-Ansah,}

Department of English, UCC.

A Disciple 


\section{$A S E M K A:$ EDITORIAL}

This Special Edition of $A S E M K A$, a bilingual literary journal of the University of Cape Coast, is published in honour of Prof. Atta Gyamfi Britwum, a revered Associate Professor of Francophone African Literature and Civilisation in the Department of French, U.C.C. It contains twenty (20) papers centred on diverse areas of teaching and research in the Humanities and on the theme of the Conference - Literature and the Humanities in the 21 Century: Interdisciplinary Perspectives - held in his honour by the Department of French, University of Cape Coast, Ghana, $13^{\text {th }}-15^{\text {th }}$ Mars, 2019. To reflect Prof. Britwum's area of research interest, the essays are arranged in two sections according to his dominant medium of instruction (French language) and speciality (Literature and Civilisation), followed by those in English language. The first section consists of a set of nine (9) essays in French spanning between themes in Literature and Language. The second section is made up of a set of eleven (11) essays in English which examine issues in literary studies, Language and Didactics, ICT and French Education, Philosophy, and Translation, among others. This special arrangement is however representative of the bilingual nature of the Journal.

\section{First Section}

Britwum, A. G.'s paper titled, “Insuffisances Théoriques Des Damnés De La Terre De Frantz Fanon", presents the Fanonian perspective as a complement to the African nationalism that informed anticolonial struggles. The study posits that African nationalism, populist in nature, for failing to target the capitalist economic base, which defines colonialism, ended up strengthening it. It concludes that Fanon's anticolonialist perspective, despite its overt radicalism, is not designed to allow a "bottom-to-top change" in colonial / capitalist society.

Kodah, M. K.'s paper titled, "Disculpation de Dieu dans le malheur des hommes: Une lecture critique de Gouverneurs de la rosée de Jacques Roumain", puts into question the responsibility of God in the suffering of men on earth and the capacity of man to make and unmake himself. The study aims at absolving God of the guilt of the miseries of men, and also questioning the atheistic or anti-religion denunciation of this narrative 
text since its publication. The study is accomplished through a critical reading and a thoughtful analysis of Jacques Roumain's Gouverneurs de la rosée within the analytical structure of literary studies and sociocriticism.

Addo-Danquah, O.'s paper, "Le récit de pensées : Une analyse comparative de Vol de nuit d'Antoine de Saint-Exupéry et La Condition humaine d'André Malraux", drawing inspirations from theorists such as Léon Edel (1961) and later Dorrit Cohn (1981), examines what Antoine de Saint-Exupéry's Vol de nuit by and André Malraux's La Condition bumaine respectively can offer on the side of representations of the interior life. The study is posited within the framework of narratological theories.

Kodah, M. K. \& Togoh Tchimavor, A. A. in "Réactions des femmes face au conflit de genre dans C'est le soleil qui m'a brûlée et Tu t'appelleras Tanga de Calixthe Beyala" examine the reactions of women to gender conflict in Calixthe Beyala's C'est le soleil qui m'a brulée and Tu t'appelleras Tanga. The study critically reflects on the various ways women in Beyala's C'est le soleil qui m'a brulée and Tu t'appelleras Tanga react to oppression and exploitation resulting from patriarchal domination. It therefore examines the sources and nature of this conflict, and how women react to it in the two novels. The study points to the fact that, much as conflict emanating from patriarchal oppression and male's domination in human societies is inimical to the rights of women, the methods used by the latter to free themselves from this state of being remain questionable, in that, these methods defy rational thinking and are also a kind of reversal oppression and domination which are equally unacceptable.

Kudi, M. D.’s paper, “La Littérature francophone face aux médias de télécommunication: Une nouvelle dynamique de la création romanesque, le cas de L'Énigme de retour et Tout bouge autour de moi de Dany Laferrière", seeks to examine how pertinent painting, photography, television, telephone etc. are to the production of the contemporary Francophone novel. The study focuses on L'Énigme de retour (2009) and Tout bouge autour de moi (2011). The analysis is based on the perspective of literary intermediality propounded by Jürgen E. Muller which is characterised by an interaction between telecommunication media and literary text. The study establishes through these selected novels that these media forms are not simply another form of expression in the novel but rather a lens through which the story is narrated. 
Gli, M.'s paper titled, "Les faces du bonheur dans Vol de nuit d'Antoine de Saint-Exupéry", analyses the faces of happiness in Antoine de Saint-Exupéry's Vol de Nuit. The study is conducted through thematic approach. This approach is complemented by Maslow's theory of human needs. The collection of data or the collection of information is purely documentary. The study therefore seeks to establish a link between individual happiness and collective happiness in Saint-Exupéry's selected narrative text.

Krakue, S. P.'s paper, “Christ haïtien : Gouverneurs de la rosée et La Bible", attempts to question Jacques Roumain's Gouverneurs de la rosée in order to elucidate the novelist's use of the biblical text in his creative activity. The study demonstrates that Jacques Roumain's narrative text turns out to borrow biblical ideas not only to develop his plot but also to design his main character.

Afari, E. S. K. \& Yegblemenawo, C. A. A. in “Apports de la télésérie à l'amélioration de la compétence d'expression orale du FLE à l'école normale." examine the impact examine the impact of the use of serial movies as teaching aid on oral expression of French language learners in Colleges of Education in Ghana with the aid of smartphones. The study discovers that the use of serial movies in teaching French boosts learners' performance in oral communication. It therefore recommends that serial movies could be used in teaching French language lessons in order to enhance the oral communication competencies among learners.

Bationo, J.-Cl.'s paper titled, "Didactique de la littérature et littérature didactique : l'exemple de la littérature africaine francophone en classe de langues étrangères au Burkina Faso", shows not only how to teach literature in language class but also how to use didactic literature to develop social skills among learners to reduce vandalism, school violence, negative stereotypes, misunderstandings of intercultural nature while cultivating social peace and living together in a context of internationalization, globalization and digital revolution. The paper focuses on francophone African Literature and posits that methodological approach used for the didactic transpositions of literary content is based on the new orientation and the redefinition of the objectives of language teaching and on the didactic models of the aesthetic reception of didactics of literature which requires putting the learner in intensive interaction with the text and motivating him/her to express himself/herself on his/her reading experiences. 


\section{SECOND SECTION - ENGLISH}

Krakue, S. P.'s paper titled, “Quod erat demonstrandum: A comparative study of narrative technique in Ama Ata Aidoo's Changes and Albert Camus' Les justes (The Just Ones)", demonstrates through textual analysis, how in Ama Ata Aidoo's Changes and Albert Camus Les justes, the authors resort to a specific form of irony to bring the discussion of issues raised to a conclusion. The technique consists in demonstrating clearly a huge discrepancy between a "fine" idea and its practical usefulness. Both authors successfully use narrative technique. Albert Camus demonstrates the hollowness of the idea of fighting for justice through revolutionary violence and Ama Ata Aidoo similarly demonstrates the fatuousness of the theory of women-emancipation-through-polygamy.

Adjandeh, E. A. analyses selected reports in Ghanaian media in relation to the clergy and identifies how Wole Soyinka's theme is reflected in these media in her paper titled, "Analysis of Wole Soyinka's Trials of Brother Jero in Relation to Ghanaian Religious Discourse". The study seeks to examine the extent to which themes in Soyinka's Trials of brother Jero play out in religious discourses in Ghana. The global nature of the issues problematized by Wole Soyinka also comes out through this study as the work set in Nigeria is analyzed in relation to the selected articles set in Ghana. The paper relies on a content analysis of Trials of Brother Jero and similar themes presented in the selected articles, and makes a few recommendations on how these religious issues could be partially, if not wholly, resolved in Ghana.

Sam, C. A.'s paper, "Decolonizing the Postcolony: Of Men, Spatial Politics and the New Nation in WA Thiongo's Wizard of the Crow", examines how Ngugi Wa Thiongo's Wizard of the Crow blatantly explores Africa's complicity in a seemingly cyclic colonization in the $21^{\text {st }}$ century and its attendant consequences for the total liberation of Postcolonial Africa. The study examines the correlation between masculine representations, spatial reorganization and futurity as alternative ways in thinking about Africa's future through Bakhtin's theory of the carnival and other such concepts as polyphony and the grotesque. The result of the analysis is that the correlation between forms of communities and forms of masculinities is an indication of a vision of hope for Postcolonial Africa. 
Kambou, M. K. \& Traore, S. A. in "Manipulation and the popular uprising in Burkina Faso in 2014", analyse the different discourses in the build-up to the popular uprising in Burkina Faso on the $30^{\text {th }}$ and $31^{\text {st }}$ October 2014. It attempts to clarify how political and civil society leaders use language and other non-linguistic elements to influence the ordinary citizens' minds and, indirectly, their actions. The analysis is premised on Van Dijk's (2006) Sociocognitive approach. The paper analyses the cognitive, the social and the discursive dimensions of manipulation in six political speeches (two speeches from Civil Society, two from the ruling party and two from the political opposition). The results suggest that the three groups manipulated their audiences, and finally, the ruling party lost following the resignation of the then Head of State, making way for a Transition government to take over the reins of governance.

De-Souza, A. Y. M.'s paper “'Test-taking Strategies of University of Cape Coast Students of French as a Foreign Language: a Case Study.” seeks to provide a description of test-taking strategies that may inform teaching and learning of French for better output in tests against the background that Ghanaian students of French as a foreign language deploy strategies that are not adequate enough in answering test items in French. The study examines data gathered right after a French test by level 200 students, using recollective verbalization protocols.

Kambou, M. K. \& Soma, L. examine in their paper titled, "Local Culture and EFL Vocabulary Learning”, the influence of learners' culture on foreign language vocabulary. The paper seeks to demonstrate that there is a link between culture and lexico-semantic errors committed by learners of English as a foreign language among Dioula speaking students in Burkina Faso. A language test composed of two written activities was used as the data collection instrument. The results revealed that the Dioula speakers' English is influenced by their culture. These results have some pedagogical implications. They, therefore, suggest that we adapt the teaching of EFL vocabulary to learners' culture.

Kabore, A. \& Nazortin, C. in "Critical Analysis of the Place and Importance of Literature in the Teaching / Learning of English and in School Leaving Certificate Examination in Burkina Faso from 1985 to 2018", analyse the types of texts given at the "Baccalaureate A" written examination in the last thirty years. In this study, quantitative and qualitative 
data are collected. Baccalaureate written English papers are the main focus of our collection. Teachers and supervisors are interviewed. The study is grounded on "Reader-Response Theory" which stresses the interactions between the reader and the text. The results of the study show that the great majority of texts proposed for "Baccalaureate A" examination, in the last thirty years, are non-literary texts.

Malgoubri, I., Sawadogo, M. \& Kambou, M. K.’s paper titled, “Digital Audio-visuals Aids and Listening in English as a Foreign Language Classrooms", is an experimental study which investigates the potential of digital audio-visuals to improve the listening skills of EFL learners in secondary schools in Burkina Faso. On the assumption that learners born around the year 2000 are digital natives, the researchers try integrating smartphone-friendly audio-visuals in their EFL classrooms in a four-week experiment involving one Experimental Group and one Control Group. The experiment aims at gauging the effectiveness of those aids operated via students' smartphones in improving learners' listening and speaking skills. Independent T-tests were used to compare the groups and Sample Paired TTests to make comparisons within groups. The study suggests that, if appropriately used, smartphones are excellent devices for language teachers and learners in this digitizing world.

Osei, R. N. \& Inusah, H.'s paper, “A Critique of the Images of Heaven in the Scriptures of the Abrahamic Religions: An Existentialist Perspective." Critically examines the scriptural images of heaven as captured in the Abrahamic religions - Judaism, Christianity and Islam - from the existentialist perspective. The paper argues that the idea of life beyond this earthly existence for all human beings in a specially prepared location by God for eternal happiness for those who obey His commands on earth called Heaven, as propounded by the Abrahamic Religions, throws up a lot of problems, especially from the existentialist perspective. The study concludes that the scriptures' constructs of heaven appear self-contradictory and fail to strike a chord with the contemporary image of the ideal society when perused from the existentialist perspective and should, therefore, be discarded.

Negedu, A. K.'s paper "Lexical Gaps and Ideological Shift in the Translation of Chinua Achebe's Things Fall Apart as "Le Monde S'effondre" in French." examines the ideological divergence between the title of the original text and the title of the translation, following an observation 
that in translating Chinua Achebe's Things Fall Apart, Michel Ligny translates directly Igbo terminologies, realities and beliefs into the French language. The paper concludes that the ideology that the translated title projects to French-readers is totally different from the ideology that the original title projects to English-readers.

Talburt, T., in "Political Transformation and Development in Africa: Lessons from Achebe's Things Fall Apart", formulates critical perspectives on the significance of Achebe's novel for the socio-political and economic transformation and development of the African continent. The paper challenges one of the central assumptions in this story that Africa falls apart as soon as it comes in contact with Europe. It questions aspects of political conservatism exhibited in Okonkwo who is suspicious of fundamental changes to his society. The discussion is based on the jollof rice principle of political hybridisation of development which proposes the amalgamation of Westernised and non-Western ideas and systems, in order to achieve economic development, rather than totally rejecting Westernisation in its entirety. The study uses examples of Western-style democracy and State intervention in Africa to demonstrate the significance of embracing some aspects of Westernisation through political hybridisation. 




\title{
Manipulation and the popular uprising in Burkina Faso in 2014.
}

\author{
Moses Kwadwo Kambou \& Sy Amidou Traore \\ Université Joseph KI Zerbo, Burkina Faso.
}

\begin{abstract}
Burkina Faso was considered to be a politically stable country in West Africa. However, this situation changed in October 2014 due to the intention of the ruling party to modify article 37 of the Constitution from two to three terms of the Presidential mandate. The Opposition and Civil Society saw in this act a way of maintaining President Blaise Compaoré in power after serving 27 years. The popular uprising in Burkina Faso on the 30 th and $31^{\text {st }}$ October 2014 can be explained from different viewpoints. From our perspective, the uprising could be in part due to the manipulation effects of the political discourses of the political stakeholders. This paper seeks to analyse the different discourses in the build up to the uprising. It attempts to clarify how political and civil society leaders use language and other non-linguistic elements to influence the ordinary citizens' minds and indirectly their actions. This Critical Discourse Analysis would be based on Van Dijk's (2006) Socio-cognitive approach. The paper analyses the cognitive, the social and the discursive dimensions of manipulation in six political speeches (two speeches from Civil Society, two from the ruling party and two from the political opposition). The results suggest that the three groups manipulated their audiences and finally the ruling party lost with the resignation of the Head of State and the takeover by the Transition government.
\end{abstract}

Keywords: Burkina Faso; Critical Discourse Analysis; manipulation; political discourse; popular uprising; Socio-cognitive approach.

\section{Résumé}

Le Burkina Faso était considéré comme un pays qui avait une certaine stabilité politique en Afrique de l'Ouest. Cependant, cette situation a changé en octobre 2014 à cause de l'intention du parti au pouvoir de modifier l'article 37 de la Constitution de deux à trois mandats présidentiels. L'opposition et la société civile considéraient cette intention comme un moyen de maintenir le 
Président Blaise Compaoré au pouvoir après 27 ans de règne. L'insurrection populaire des 30 et 31 octobre 2014 au Burkina Faso peut s'expliquer de différents points de vue. De notre point de vue, le soulèvement pourrait être en partie dû aux effets de la manipulation dans le discours des acteurs politiques. Cet article analyse les différents discours d'avant l'insurrection. Il tente de clarifier la manière dont les dirigeants politiques et ceux de la société civile ont utilisé le discours politique pour influencer le mental des citoyens ordinaires et, indirectement, leurs actions. Cette analyse critique du discours sera basée sur l'approche sociocognitive. L'article analyse les dimensions cognitives, sociales et discursives de la manipulation dans six discours politiques (deux discours de la société civile, deux du parti au pouvoir et deux de l'opposition politique). Les résultats montrent que les trois groupes ont manipulé leurs audiences et que le parti au pouvoir a finalement perdu. Ce qui a entrainé la démission du Chef de l'État et la prise de pouvoir par le gouvernement de transition.

\section{MOTS CLÉS: Burkina Faso; insurrection populaire; manipulation; discours politique; Analyse critique du discours; approche socio- cognitive.}

\section{Introduction}

Politics is in part viewed as "the struggle for power, between those who seek to assert and maintain their power and those who seek to resist it" (Chilton 2004, p. 3). In this struggle for power, discourse (including language and other semiotic features) is most of the time used as an instrument to gain the support of public opinion. In such an endeavor, it is common that the political actors manipulate other people. In other words, politicians make the ordinary people believe and do things that are in the interest of the these political leaders and against the interest of the ordinary citizens (Van Dijk, 2006). This way of going into politics is particularly commonplace in most of African countries where political protagonists are permanently in search of the support of Public opinion to win political battles and therefore satisfy their own political agenda. Burkina Faso, a West African country, is no exception since the period 2014 was marked by the political euphoria resulting in the intention of President Blaise Compaoré, who had spent 27 years in power, to modify article 37 of the constitution in order to be candidate in the 2015 presidential elections. This decision divided the political class and civil society of the country into two drastically opposed groups. On one side, we had the "Front Republicain" including the Ruling party and allies who were favourable to the constitutional change and on the other, the coalition of the opposition 
parties organized around the "Chef de File de l'Opposition Politique (CFOP)" and their allies: some of the civil society organizations strongly against the constitutional change. That was the beginning of 'the battle' for the support from public opinion. This battle was fought through rallies and counter-rallies during which several political speeches and interviews were delivered by both groups before thousands of ordinary citizens. All these resulted in the October $30^{\text {th }}$ and $31^{\text {st }} 2014$ popular uprising, one of the greatest demonstrations ever held in Burkina Faso.

In this article, we examine six political speeches produced in 2014 in order to determine the contribution of political discourses in the popular uprising. To achieve such a purpose, the following research questions will be answered:

1- What were the discursive strategies used in 2014 by Political and Civil society leaders to influence ordinary people's minds?

2- How did these discursive strategies affect ordinary citizens' actions?

This study is carried out within the perspective of Critical Discourse Analysis. The specific approach used to address our research questions is the Socio-cognitive approach as developed in Van Dijk (2006).

\section{Literature Review}

\section{Theoretical framework Critical Discourse Analysis}

Critical Discourse Analysis (CDA) is considered to be a broader movement within discourse analysis having several approaches (Jorgensen and Philips, 2002). These approaches include Fairclough's Critical Discourse Analysis, the Discourse-Historical Approach by Wodak and colleagues, Van Dijk's Socio-cognitive approach to list but a few. For Van Dijk (1995, p.17), "CDA emerges from critical linguistics, Critical semiotics, and the sociopolitically conscious and oppositional investigation of language, discourse and communication." This socio-political consciousness is noticeable in CDA research where emphasis is laid on the issues of social power abuse, social changes and other burning issues.

Since the participants of a communicative event are not always "aware of how powerful or powerless they are in discourse terms" (Flowerdew 2008, p. 195), it is the role of CDA to reveal these relationships and structures of power and dominance in text and talk. Therefore, the aim of CDA is to "uncover, reveal or disclose what is implicit, hidden or not immediately obvious in relations of discursively enacted dominance and their underlying 
ideologies" (Van Dijk, 1995, p.18). In other words, the role of CDA is to make obvious ideologies that are concealed in text and talk.

Van Dijk (1995) goes on by explaining that 'CDA focuses on strategies of manipulation, legitimation, the manufacture of consent and other discursive ways to influence the mind (and indirectly the actions) of people in the interest of the powerful' (p.18). In doing so, CDA aims at changing social practices and relationships into more equal and acceptable ones. CDA is 'critical' because it addresses social problems. That is why, Fairclough (2012, p. 452) argues that CDA focuses 'on processes of social change in their discourse aspect'. These processes of social changes also include social movements such as uprisings.

\section{Van Dijk's (2006) Socio-cognitive Approach to manipulation}

Van Dijk (2006) distinguishes between legitimate forms of mind control (including persuasion, education, providing information) and the illegitimate ones (for example, manipulation). Van Dijk explains that manipulation differs from persuasion because 'in persuasion the interlocutors are free to believe or act as they please, depending on whether or not they accept the arguments of the persuader, whereas in manipulation recipients are assigned a more passive role: they are victims of manipulation' (2006, p. 361).

From this point of view, manipulation in the 'communicative' sense appears to be a form of social power abuse which consists in influencing the manipulated people's mind.

The manipulated groups are then forced to act in the interest of the manipulator and most of the time against their own interest. Relevant to this study, Van Dijk's (2006) three dimensional sociocognitive approach includes three analytical components namely social analysis, cognitive analysis and discourse analysis.

\section{Studies on Manipulation}

Manipulation is a crucial notion in Critical Discourse Analysis (Van Dijk, 2006) that has drawn much more attention among critical discourse analysts since the 9/11 terrorist attacks in the United States. Since then, a large number of studies have been carried out on this particular notion. Some of these studies exhibit some theoretical disagreements and others apply the already existing theories to specific issues of manipulation. Because of space limitation, we mention in this article just very few of these studies and ignore these theoretical disagreements around the concept of manipulation.

Van Dijk (2006) was an attempt to provide a multidisciplinary theoretical approach to manipulation that includes the analysis of the social, 
cognitive and discursive dimensions of manipulation as expressed in text and talk. He justifies his 'triangulated' three dimensional approach to manipulation by the fact that manipulation is a social issue because it is an illegitimate domination that confirms social inequality, it is a cognitive phenomenon since it is a strategy of mind control that 'involves the interference with processes of understanding, the formation of biased mental models and social representations such as knowledge and ideologies' (Van Dijk, 2006, p.359). Finally, manipulation is discursive because of its use of forms and formats of ideological discourse.

Maillat \& Oswald (2009) propose a rather different and pragmatic model of manipulation in the field of cognitive psychology. They reject the other approaches to manipulation. On the basis of their consideration that manipulation is 'essentially a cognitive process, which mislead context selection' (p.363), they propose the Relevance Theory.

Taking another perspective, Sarfo and Krampa (2013) analyze six political speeches from Bush and Obama using Van Dijk's (1998) concept of Critical Discourse Analysis and the notion of power as control (Fairclough, 2001; Rudyk, 2007). Their study revealed that the notion of power as control, mind control and context control were common features of Bush's and Obama's speeches and that both Obama and Bush make use of a careful selection of emotionally charged vocabulary and expressions to have a specific impact on their listeners.

Cabrejas- Peñuelas (2017) was another researcher who addressed the issue of manipulation in political discourse.

The researcher combines Van Dijk's (2006) approach with a corpus based one to analyze the discursive strategies of manipulation employed in a parliamentary speech by the Spanish Prime Minister Mariano Rajoy to defend himself and his Party against accusation of corruption.

The study concluded that the Prime Minister's speech presents characteristics of ideological discourse, self-legitimation and uses appropriate contextual constraints and defensible semantics of presentation.

The papers mentioned above present some similarities with the current study in that they all address the issue of manipulation. However, they are different in their focus and their specific theoretical frameworks. The current paper focuses on the issue of manipulation in the political discourses in the build up to a popular uprising and employs specifically Van Dijk's (2006) sociocognitive approach to manipulation. 


\section{Methodology}

\section{Data sources}

The data of the current study were collected from secondary sources and consist of one major 'genre' of political discourse, i.e. the political speech. We collected political speeches from three TV stations in Ouagadougou, the capital city of Burkina Faso. Ouagadougou was purposefully selected for data collection because it is the city that has almost all the major TV stations of Burkina Faso. The first TV station we visited was 'Radiodiffusion Television du Burkina'(RTB), a public TV station of the country which is watched almost nationwide. In addition to this T.V. station, two private ones, that is, 'Canal 3 television' and 'BF1' were selected because they were very active and popular during the period 2014. Audiovisual speeches were preferred over written or audio ones because audio-visual data offer some extra-linguistic items like pictures, gestures, background noise that are necessary for the current analysis. Therefore, radio stations, newspapers and magazines were excluded from our data sources because audio-visual records are not logically found in Radio stations, newspapers and magazines.

\section{Data collection and sampling procedure}

Data collection concerns excerpts of political speeches broadcasted in T.V. reports in 2014. Only political speeches dealing with the change of article 37 of Burkina's constitution were selected.

First of all, a request was sent to the three selected T.V stations for the collection of the political speeches in their archives. The political speeches were retrieved in the form of excerpts from audio-visual press reports. Data collection started in February, 2019 and ended in March, 2019 and involved the political speeches delivered in 2014 during major political rallies on the issue of constitutional change in Burkina Faso.

Out of a total of twelve (12) political speeches collected, six (6) were purposefully selected. To be more specific, two speeches from the leaders of the coalition of opposition parties, two from the presidential majority and two from the civil society organizations formed our sample. The sample speeches were delivered on January $18^{\text {th }}$, June $21^{\text {st }}$, October $27^{\text {th }}$ and October $28^{\text {th }}, 2014$. The selected excerpts of speeches vary in length depending on the TV stations that broadcasted them. For the purpose of a 'discursive-semiotic analysis' (Van Dijk, 2015, p.65), we made screenshots of the video recording. 


\section{Data transcription and translation}

For Atkinson and Heritage quoted in McLellan et al. (2004, p.64), the 'production and use of transcripts are 'research activities' and should not be approached as merely a 'technical detail' that precedes analysis'. Hence, the way transcripts are generated is of paramount importance since transcripts should provide structural details such as pauses, intonations, hesitations, that are necessary to the analysis. In order to generate reliable transcripts, we transcribed the data following Jefferson's (1984) Transcription Notation. Then, we proofread the transcripts against the audio-visual speeches. The transcripts were translated into English using 'Google Translator' to obtain a draft from which editing was effected. For easy reference, we numbered each extract of speeches and provided the names of speakers.

\section{Data analysis}

The current research takes into account one major strategy of mind control described in Van Dijk (2006), that is, manipulation. The qualitative research method was employed to analyze the data. The rationale for using this method is that it allows researchers to deal with social reality in a suggestive but scientific way (Sarfo and Crampa, 2013).

The approach employed to analyze the data is Van Dijk's (2006) three dimensional Sociocognitive approach which includes the social, cognitive and discursive dimensions of manipulation in the political speeches under investigation.

Social analysis was carried out around the concepts of power and domination.

We identified the powerful group (the manipulator) on the basis of group membership, profession, institutional position, material or symbolic resources and social status. We rely on screenshots of the leaders of the Opposition Parties, those of the ruling party and the ordinary citizens during their speeches or interviews to show their access to mass media and public discourses. We did so with the aim of identifying the manipulators and the manipulated since in Van Dijk (2006, p.362) it is clearly stated that in order to be able to manipulate many others through texts and talk, one needs to have access to some forms of public discourse'.

Cognitive analyses were carried out around cognitive components such as attitudes, beliefs, knowledge, ideologies and the context model of the participants that permit in Van Dijk's sense to link discourse to society and are therefore, crucial for the production and comprehension of discourse. 
Discursive analysis consisted in investigating in the sampled political speeches the discourse structures such as ideological polarization, Positive selfPresentation and Negative others' Presentation, rhetorical devices, argumentation, and other strategies the political and civil society leaders used to influence the ordinary people's mind and then their actions.

\section{Results and Discussion}

\section{Social analysis}

The analysis of the social groups under investigation showed that the members of two of them hold privileged institutional positions. These two groups are leaders of the presidential majority and also the coalition of opposition and civil society leaders. Most of the members of the two groups have high social status and professions (university professors, famous singers, lawyers, MPs), they possess material and symbolic resources (money, decisionmaking ability) and they have a preferential access to public discourse and mass media.

However, most of the ordinary citizens do not have such statuses, professions, resources and access to public discourse. Ordinary people are essentially students, traders, farmers, jobless people etc. who had little access to media.

In the three images of figure 1 below, we respectively have from left to right an ordinary citizen, a leader of the majority party and a leader of the coalition of opposition parties. We measured their access to media.

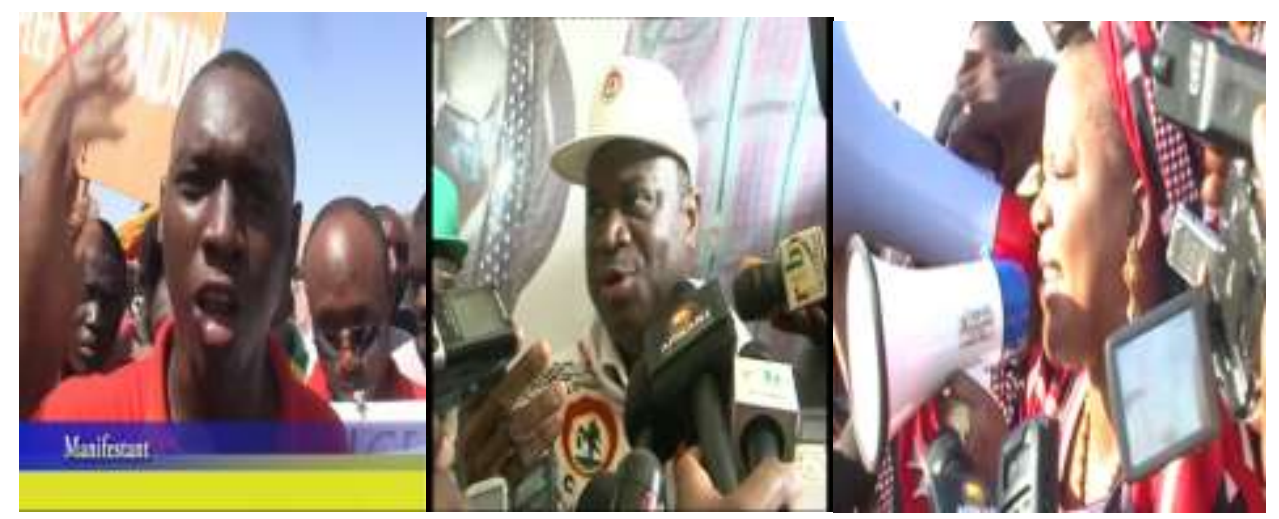

Figure1: The different social groups' access to public discourse and mass media.

Obviously, the number of microphones shows clearly that the political leaders both from the Presidential majority and the Opposition in the last two pictures have a privileged access to media and public discourses. Such an 
access gives them power and allows them to dominate (manipulate) the ordinary people who have a limited access to media as illustrated in picture 1 of figure 1 above. Such an analysis helped us to determine the power of each group and their members (Van Dijk, 2006) and to identify the dominant groups as well as the dominated one. Based on the above mentioned characteristics, the political and civil society leaders are considered as part of the dominant groups and the ordinary people are the dominated groups.

\section{Cognitive and discursive aspects of manipulation.}

\section{Strategies of Ideological polarization.}

Ideological polarization refers to the strategy of emphasizing 'Our Good Things and Their Bad Things' or de-emphasizing 'Their Good Things' and 'Our Bad Things' (Van Dik, 2015).

Both the political speeches of the Presidential majority and those of the coalition of opposition parties and civil society organisations exhibit strategies of ideological polarization. This strategy is obvious in extracts (1) and (2).

(1) "Quand il y a n'en qui veulent appliquer la constitution et d'autres sont en rébellion avec la constitution, qu'est-ce qu'on fait? (...) Alors, allons vers le peuple! C'est le peuple qui va trancher." (Herman Yaméogo, leader de la majorité présidentielle)

(1) 'When some want to apply the constitution and others are in rebellion with the constitution, what do we do? So let's go to the ordinary people, it's the ordinary people who will decide.' (Herman Yaméogo, leader of the majority party) (Our own translation)

The referents of the deictic expressions 'some' and 'others' are taken for granted by Herman Yameogo because in his context model, he and his audience have some socially shared knowledge. What is obvious here is that Mr Yameogo depicts 'some' (his In-group) as democrats, peaceful and loyal to the constitution and 'Others' (his Out-groups) as enemies of Peace and Security, troublemakers or even as rebels (see extract 1 ).

Similarly, in extract (2) below, Zéphirin Diabré implicitly uses Van Dijk's strategy of Positive self-presentation and Negative Other-presentation through a series of anaphoric sentences. He qualified his own group as honest and caring for the future of Burkina Faso whereas his opponents are corrupted and careless about the future of the country. This strategy of legitimation of 
Zéphirin and his in-group's position on the change of article 37 aims at searching the support of his audience.

(1) "Aux députés du groupe CDP, du Groupe ADF et du Groupe CFR, je leur demande de rester avec le peuple.

Je leur demande de respecter leur dignité de Burkinabè.

Je leur demande de ne pas se laisser intimider.

Je leur demande de ne pas se laisser corrompre.

Je leur demande de penser à l'avenir de leurs enfants.

Je leur demande de penser à l'avenir du Burkina Faso."

(Zéphirin Diabré, Chef de Fil de l'Opposition Politique)

(2) 'I appeal to the M.Ps of CDP Group, those of ADF Group and the CFR Group.

$I$ ask them to stay on the side of the people.

I ask them to respect their Burkinabe dignity.

I ask them not to be intimidated.

I ask them not to be corrupted.

I ask them to think about the future of their children.

I ask them to think about the future of Burkina Faso.'

(Zéphirin Diabré, leader of the Coalition of the Opposition Parties)

(Our own translation)

The extracts (1) and (2) above have manipulative effects on the ordinary people because they aim at positively changing the audience's attitude and actions towards the speaker's own group and negatively towards the speaker's opponents.

\section{Argumentation strategies}

The results show that the political leaders use emotional arguments to appeal to ordinary people (see extract (3) below).

(3) (...) Notre adversaire (\#3), notre adversaire, c'est Blaise Compaoré, notre adversaire c'est son gouvernement, notre adversaire c'est le CDP, notre adversaire c'est le Front Républicain et notre adversaire c'est tous ceux qui profitent de la quatrième république(...). (Zéphirin Diabré, Opposition) (...)Our opponent (\#3 ), our opponent (.) is Blaise Compaoré, our opponent (.) is his government, our opponent(.) is the CDP, our opponent (.) is the Republican Front and our opponent (.) is all those who have 
favours from the Fourth Republic. (Zéphirin Diabré, leader of the Opposition)(Our own translation)

Each political group urges the ordinary citizens to take radical actions towards the opposed group. For instance in extract (3), Zéphirin Diabré, the leader of the coalition of opposition parties insisted on the fact that their opponent is Blaise Compaoré, his government, his political party and all those who support Blaise Compaoré. The repetition of 'Our opponent' followed by pauses implicitly urges the citizens to blame Blaise Compaoré, his political party and his Supporters. In doing so, Zéphirin Diabré brings the ordinary people to change their attitudes towards the majority parties.

Similarly, this emotionally charged argument is used in the speech of one of the civil society leaders as is the case in extract (4) below.

(4) Le pouvoir est dans la rue, le pouvoir est avec le peuple (Samsk. Le Jah., leader de la société civile)

(4) (...) Power is in the street, power belongs to the people (...). (Samsk Le Jah., Civil society leader) (Our own translation).

Obviously, the statement of Samsk Le Jah has an influence on the addressees' behaviours since it is a clear call for action. In other words, the ordinary people should go into the street and take 'the power'.

\section{The use of biased questions}

The questions asked by both speakers in extract (5) appear at first sight as Yes/no questions but in reality the speaker uses them to restrict his audience in their answers. Obviously, in extract (5), the addressees are given little choice or even no choice to answer the speakers' questions by 'yes' since the speaker's 'that' refers to a 'coup' or 'civil war'. The obvious answers are 'no' and this is due to some contextual realities of the speeches. The questions are asked during political rallies where the purpose of people's gathering is to support the speaker's position on the constitutional change. The speaker is therefore implicitly forcing the audience to support his hidden political agenda (see extract 5 below).

(5) '(...) Si on laisse les gens se tirailler, on va vers le coup d'état, on va vers la guerre civile. Est-ce que vous voulez ça au Burkina Faso? Est-ce que voulez ça au Burkina Faso?' (Herman Yameogo, leader d'un parti politique de la Majorité Présidentielle) 
(5) '(...) if we let people get into clash, it will all end in a coup, it will all end in civil war. Do you want that in Burkina Faso? Do you want that in Burkina Faso? ((Herman Yameogo, leader of a majority party) (Our own translation)

It is the same case in extract (6) where Guy Hervé Kam subtly imposes the answer 'No' to his audience so that they may do what he wants them to do.

(6) "Nous disons que toutes les générations doivent découvrir leur mission. Ils doivent la réaliser ou la trahir. Est-ce que nous réalisons notre mission ou nous la trahissons? Si nous la réalisons, on ne bouge pas de la ville de Ouagadougou aujourd'hui si Blaise Compaoré ne nous dit pas qu'il retire son projet." (Guy Hervé Kam, Porte-parole du Balai Citoyen, une organisation de la société civile)

(6) 'We say that all generations must discover their mission. They must realize it or betray it. Are we fulfilling our mission or are we betraying it? If we realize it, we do not move from the city of Onagadongou today unless Blaise Compaoré tells us he withdraws his project.' (Guy Hervé Kam, Spokesperson of the "Balai Citoyen", a Civil Society Organisation) (Our own translation)

\section{The use of 'number game'}

Number game is strategically used by the presidential majority as well as the coalition of opposition parties and civil society organisations. For instance, we have in extract (7):

(7) Une mobilisation exceptionnelle, (...) Cette grande mobilisation, cette gigantesque mobilisation atteste votre disponibilité, votre engagement permanent!' (Assimi Koanda, leader de la majorité présidentielle)

(7) 'An exceptional mobilization, (...) this great mobilization, this gigantic mobilization proves your availability, your permanent commitment!' (Assimi Koanda, leader of the majority party)(Our own translation)

(8)"Depuis Maurice Yaméogo à Sankara, ils ont totalisé de 1960 à 1987, 27 ans de pouvoir et Blaise Compaoré à lui seul de 1987 à 2014 a fait 27 ans! Est-ce qu'on va ajouter encore? Est-ce qu'on va ajouter encore?, est ce qu'on va ajouter encore?" (S. Sérémé, leader d'un parti d'Opposition).

From Maurice Yameogo to Sankara, all of them spent from 1960 to 1987 a total of twenty-seven years on power and Blaise Compaoré alone has spent 27 years from 1987 to 2014.' Are we going to allow him more? Are we going to allow bim more?'

(S. Sérémé, leader of an opposition party) 
Assimi Kouanda, the speaker in extract (7) implicitly uses numbers through a series of hyperbole (for instance, 'exceptional mobilization', 'gigantic mobilization') to draw his audience's attention on their 'availability and commitment'. However, he strategically omitted the indirect object of the sentence by implying in his context model that his audience knows that it is an 'availability' and a 'commitment' to follow the presidential majority in the project of modification of article 37.

The extract (7) is therefore, manipulative since it implicitly urges the audience (ordinary people) to adopt the reformist ideology to the best interest of the leading political group.

Unlike in extract (7), the political leader in extract (8) explicitly uses number game to draw her audience's attention on the duration of President Compaoré's presidential mandate and the necessity to put an end to it. The speaker's intention is to radicalize her audience. In doing so, she led the ordinary citizens to change their attitudes towards President Compaoré and to take actions to prevent Blaise Compaoré from modifying the constitution and renew his presidential term of office. Such actions are more to the interest of the political Opposition whose purpose is to lead the country.

The repetition of 'strategic' yes/no questions like 'Are we going to allow bim more? Are we going to allow him more?' is an invitation to the people to prevent Blaise Compaoré from having a new presidential term of office.

\section{Discursive-semiotic strategies of manipulation.}
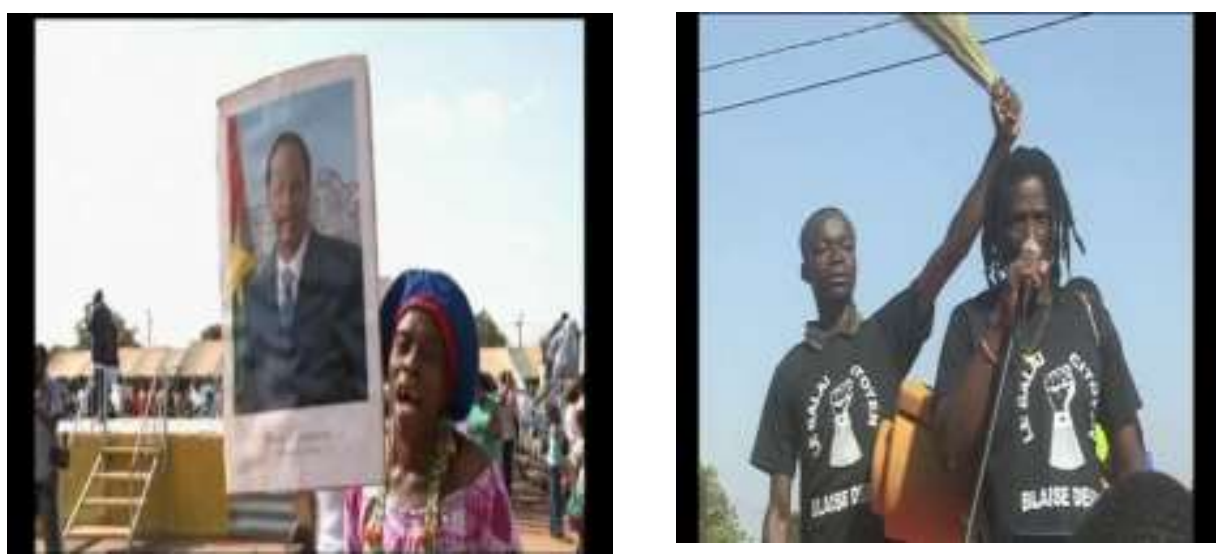

Figure 2: A majority and a civil society activists during two opposed political rallies on the change of article 37 of the constitution.

In figure 2, the debate shifts from the issue of constitutional change to the personality of President Blaise Compaoré. Politicians and civil society 
leaders use semiotic tools of manipulation in order to have public opinion on their sides. Hence, those who are against the constitutional change are considered as enemies of Blaise Compaoré. For instance, in the picture on the right (Figure 2), the two young men from the civil society are wearing black Tshirts on which it is written in capital letters 'BLAISE GET LOST'. This is considered as manipulative since it intends to make the audience feel resentment against Blaise Compaoré and therefore change their attitudes towards him.

Similarly, in the picture on the left of the figure 2 above, a woman is exhibiting a picture of President Compaoré. This is due to the political influence on her. In her mental model, supporting the change of article 37 is loving Blaise Compaoré.

\section{Conclusion}

The study attempted to determine the contribution of political discourses in the build up to the popular uprising in Burkina Faso in 2014. Van Dijk's (2006) categories of manipulation were, thus, investigated in the selected speeches and the study concluded that the political speeches contain a great deal of manipulative strategies. The study took into consideration social, cognitive and discursive characteristics of manipulation and shows that manipulative strategies affect ordinary citizens in diverse ways. Based on the results of the current study, the following recommendations were made by the researchers: ordinary Citizens should reinforce their knowledge about burning political issues in order to avoid being manipulated by politicians and

Citizens need to be trained on manipulative strategies. This study has implications for critical discourse analysts and future research could investigate how ordinary citizens reacted discursively to these manipulative strategies.

\section{References}

Cabrejas- Peñuelas, A. B. (2017) Manipulation as an ideological tool in the political genre of Parliamentary discourses. Pragmatics. 27: 2, 207-234.

Chilton, P. (2004). Analyzing Political Discourse. Theory and Practice. London: Routledge.

Fairclough, N. (2012). Critical discourse analysis. International Advances in Engineering and

Technology (IAET). ISSN: 2305-8285 Vol.7 International Scientific Researchers (ISR) 
Flowerdew, J. (2008). Critical discourse analysis and strategies of resistance in V. K.

Bhatia, J. Flowerdew and R. H. Jones's Advances in Discourse Studies. London \& New

York: Routledge. Jefferson, G. (1984) “Transcription Notation," in Atkinson J. and Heritage J. (eds), Structures of Social Interaction, New York: Cambridge University Press, 1984.

Jorgensen, M. \& Philips, L.J. (2002). Discourse Analysis as Theory and Method. London: Sage Publication.

Maillat \& Oswald (2009). Defining Manipulative Discourse: The Pragmatics of Cognitive Illusions. International Review of Pragmatics1: 348-370.

McLellan, E., K. M. McQueen \& J. L. Neidig (2003) Beyond the Qualitative Interview: Data Preparation and Transcription. Field Methods, Vol. 15, No. 1, 63-84.

Sarfo, E. \& Crampa, E. A. (2013) Language at War: A Critical Discourse Analysis of Speeches of Bush and Obama on Terrorism. International J. Soc. Sci. \& Education Vol.3 Issue 2: 378-390.

Van Dijk, T. A. (1995).Aims of Critical Discourse Analysis. Japanese Discourse Vol I; 17-27.

Van Dijk, T. A. (2006a). Discourse and Manipulation. Discourse \&Society. Vol 17(2): 359-383

Van Dijk, T. A. (2006b). Discourse, context and cognition. Discourse Studies. Vol 8(1):159-177.

Van Dijk,T. A. (2015). Critical Discourse Studies: A sociocognitive Approach. In Ruth Wodak

\& Michael Meyer (Eds.), Methods of critical discourse analysis. Third Edition. (pp.63-85). London: Sage.

Wodak, R. (2001). The discourse-historical approach. In R. Wodak \& M. Meyer (Eds.), Method of Critical Discourse Analysis (pp. 63-95). London: Sage. 


\section{Appendix1: Jefferson's Transcription Notation}

Jeffersonian Transcription Notation includes the following symbols:

\begin{tabular}{|c|c|c|}
\hline Symbol & Name & Use \\
\hline$[$ text $]$ & Brackets & $\begin{array}{l}\text { Indicates the start and end points of } \\
\text { overlapping speech. }\end{array}$ \\
\hline$=$ & Equal Sign & $\begin{array}{l}\text { Indicates the break and subsequent } \\
\text { continuation of a single interrupted } \\
\text { utterance. }\end{array}$ \\
\hline $\begin{array}{ll}(\# & \text { of } \\
\text { seconds) }\end{array}$ & Timed Pause & $\begin{array}{l}\text { A number in parentheses indicates the time, } \\
\text { in seconds, of a pause in speech. }\end{array}$ \\
\hline$()$. & Micropause & A brief pause, usually less than 0.2 seconds. \\
\hline . or $\downarrow$ & $\begin{array}{l}\text { Period or } \\
\text { Down Arrow }\end{array}$ & Indicates falling pitch. \\
\hline ? or $\uparrow$ & $\begin{array}{l}\text { Question Mark } \\
\text { or Up Arrow }\end{array}$ & Indicates rising pitch. \\
\hline , & Comma & $\begin{array}{l}\text { Indicates a temporary rise or fall in } \\
\text { intonation. }\end{array}$ \\
\hline- & Hyphen & $\begin{array}{l}\text { Indicates an abrupt halt or interruption in } \\
\text { utterance. }\end{array}$ \\
\hline$>$ text $<$ & $\begin{array}{l}\text { Greater than / } \\
\text { Less than } \\
\text { symbols }\end{array}$ & $\begin{array}{l}\text { Indicates that the enclosed speech was } \\
\text { delivered more rapidly than usual for the } \\
\text { speaker. }\end{array}$ \\
\hline$<$ text $>$ & $\begin{array}{l}\text { Less than / } \\
\text { Greater than } \\
\text { symbols }\end{array}$ & $\begin{array}{l}\text { Indicates that the enclosed speech was } \\
\text { delivered more slowly than usual for the } \\
\text { speaker. }\end{array}$ \\
\hline$\circ$ & Degree symbol & $\begin{array}{l}\text { Indicates whisper or reduced volume } \\
\text { speech. }\end{array}$ \\
\hline ALL CAPS & Capitalized text & $\begin{array}{l}\text { Indicates shouted or increased volume } \\
\text { speech. }\end{array}$ \\
\hline underline & Underlined text & $\begin{array}{l}\text { Indicates the speaker is emphasizing or } \\
\text { stressing the speech. }\end{array}$ \\
\hline$:::$ & Colon(s) & Indicates prolongation of an utterance. \\
\hline
\end{tabular}




\begin{tabular}{lll}
\hline (hhh) & Audible exhalation \\
\hline ? or (.hhh) & High Dot & Audible inhalation \\
\hline (text $)$ & Parentheses & $\begin{array}{l}\text { Speech which is unclear or in doubt in the } \\
\text { transcript. }\end{array}$ \\
\hline$(($ italic text & $\begin{array}{l}\text { Double } \\
\text { Parentheses }\end{array}$ & Annotation of non-verbal activity. \\
\hline
\end{tabular}

Jeffersonian Transcription Notation is described in G. Jefferson, "Transcription Notation," in J. Atkinson and J. Heritage (eds), Structures of Social Interaction, New York: Cambridge University Press, 1984.

\section{Appendix 2: Transcripts of extracts of the sampled political speeches}

'Aux députés du groupe CDP, du Groupe ADF et du Groupe CFR, je leur demande de rester avec le peuple. Je leur demande de respecter leur dignité de Burkinabès. Je leur demande de ne pas se laisser intimider. Je leur demande de ne pas se laisser corrompre. Je leur demande de penser à l'avenir de leur enfant. Je leur demande de penser à l'avenir du Burkina Faso. Mais nous sommes conscient que le 30 Octobre là, il y aura 127 bulletins "Non" et zéro bulletins "Oui".

La première revendication de notre campagne, elle est simple: le retrait pur et simple de la loi. Et l'opposition politique demande encore aux Président Blaise Compaoré, dès ce midi de retirer purement et simplement le projet de lois portant modification de l'article 37 de la constitution.

Mes chers camarades, pour mener à bien cette campagne, l'opposition donnera à chaque fois des mots d'ordres précis ou organisera des activités bien précises avec vous.

Pour que notre campagne de désobéissance civil soit un succès, comme on l'a toujours fait, et comme on l'a encore fait ce matin, nous devons éviter les casses et des violences, nous devons éviter de nous prendre aux personnes physiques, nous devons éviter de détruire les biens publics (pause). Notre adversaire (pause), notre adversaire c'est Blaise Compaoré, notre adversaire c'est son gouvernement, notre adversaire c'est le CDP, notre adversaire c'est le Front Républicain et notre adversaire c'est tous ceux qui profitent de la quatrième république.

(Zéphirin Diabré, Opposition politique)

Depuis Maurice Yaméogo à Sankara, ils ont totalisé de 1960 à 1987, 27 ans de pouvoir et Blaise Compaoré à lui seul de 1987 à 2014 a fait 27 ans! Est-ce 
qu'on va ajouter encore? Est-ce qu'on va ajouter encore?" (S. Sérémé, Opposition).

Quand il y a un litige politique dans un pays. Quand certains tirent à gauche et d'autres tirent à droite. Quand il y a n'en qui veulent appliquer la constitution et d'autres sont en rébellion avec la constitution! Qu'est-ce qu'on fait? $\mathrm{Si}$ on laisse les gens se tirailler, on va vers le coup d'état, on va vers la guerre civile. Est-ce que vous voulez ça au Burkina Faso? Est-ce que voulez ça au Burkina Faso? Alors, allons vers le peuple! C'est le peuple qui va trancher.

(Herman yaméogo, majorité présidentielle)

Une mobilisation exceptionnelle qui montre et qui démontre à ceux qui viennent à Bobo et qui empruntent les sentiers étroits pour pouvoir faire une file indienne que entre eux et le Front Républicain, il n'y a pas de comparaison possible! Cette grande mobilisation, cette gigantesque mobilisation atteste votre disponibilité, votre engagement permanent!

(Assimi Koanda, majorité Présidentielle)

Nous disons que toutes les générations doivent découvrir leur mission. Ils doivent la réaliser ou la trahir. Est-ce que nous réalisons notre mission ou nous la trahissons? Si nous la réalisons, on ne bouge pas de la ville de Ouagadougou aujourd'hui Blaise Compaoré ne nous dit pas qu'il retire son projet.

(Guy Hervé Kam, société civile)

Nous là, on respect celui qui nous respecte. C'est à cause de nous il est président!

Maintenant le pouvoir est dans la rue, le pouvoir est avec le peuple ! (Samsk Le Jah., société civile) 
